\title{
Effects of supplementation with hydrogenated fish fat on digestion in dairy cows
}

\author{
M Doreau \\ INRA, Laboratoire de la Sous-Nutrition, Theix, F 63122 Saint-Genès Champanelle, France
}

(Received 26 September 1991; accepted 6 January 1992)

\begin{abstract}
Summary - Three dry cows received a diet based on maize silage according to a $3 \times 3$ Latin square design, without or with a fat supplement composed either of crystalline hydrogenated fish oil (rich in arachidic and behenic acids) or rapeseed oil (rich in unsaturated fatty acids). The fatty acid content of the diets was $1.5,8.6$ and $8.7 \%$ dry matter (DM) respectively. Fish oil supplementation did not decrease fibre digestion and did not modify ruminal fermentation, in contrast to rapeseed oil which altered ruminal fermentation. Digestibilities of lipids and fatty acids were lower when the diet was supplemented with fish oil than when the other 2 diets were fed because of the low digestibility of all fatty acids, whatever the chain length.
\end{abstract}

cow / digestion / lipids

Résumé - Effets d'une supplémentation en huile de poisson hydrogénée sur la digestion chez la vache. Trois vaches taries ont été utilisées dans un schéma en carré latin. Elles ont reçu soit un régime témoin $(T)$ à base d'ensilage de maïs, soit ce régime supplémenté avec de l'huile de poisson hydrogénée (HPH, riche en acides arachidique et béhénique) présentée sous forme cristalline, soit le régime témoin supplémenté avec de l'huile de colza (HC, riche en acides gras polyinsaturés). La teneur en acides gras de ces trois régimes était respectivement de 1,5;8,6 et 8,7\% de la matière sèche. La supplémentation en huile de poisson n'a pas modifié la digestibilité des parois végétales et les fermentations du rumen, contrairement à l'addition d'huile de colza : la digestibilité du NDF a été respectivement de 73,$9 ; 72,8$ et 63,5 pour les régimes $T$, HPH et $H C$. En revanche, la digestibilité apparente des lipides et des acides gras a été plus faible pour le régime $\mathrm{HPH}$. Cette dernière a été respectivement de 71,$7 ; 44,9$ et $72,0 \%$ pour les régimes $T$, HPH et $H C$. La digestibilité des acides gras du régime HPH a été faible quelle que soit leur longueur de chaine.

vache / digestion / lipides

\section{INTRODUCTION}

Fish oils have seldom been used in feeding cows, primarily because of the drop in milk fat percentage observed with these supplements (review by Opstvedt, 1984). However, the few experiments on diges- tion in diets containing fish oils did not show marked disturbances in carbohydrate digestion, either when fish oils were hydrogenated (Sundstøl, 1974) or not (Sutton et al, 1975). There is no evidence of a decrease in ruminal digestibility when these kinds of lipids are added to the diet. 
Moreover, the digestibility of such lipids in the small intestine appears high (Andrews and Lewis, 1970).

The recent trends in dairy cow nutrition (increasing the fat content of diets, without the necessity of maintaining a high buttertat content) have stimulated renewed interest in fish oil supplementation. In addition, the use of technological treatments such as crystallisation may be helpful in avoiding disturbances in rumen fermentation.

In this trial, the consequences of hydrogenated fish oil supplementation on fat digestibility in cows have been studied. In order to improve the interpretation of results, this fat-supplemented diet was compared: 1), to a control diet, without lipid addition; and 2), to a diet supplemented with rapeseed oil that is efficiently digested in the intestines but which is known to decrease fibre digestion in the rumen.

\section{MATERIAL AND METHODS}

\section{Animals, experimental design and diets}

Three non-lactating Holstein cows, weighing on average $753 \mathrm{~kg}$ and fitted with ruminal cannulae, were utilized in a $3 \times 3$ Latin square design. Each period consisted of 3 or 4 weeks for adaptation to the diets and 1 week for experimental measurements.

Three diets were fed to the cows (table 1). The control diet (C) consisted of $70 \%$ maize silage and $30 \%$ concentrates on a dry matter (DM) basis, of urea and of mineral premix containing $14 \% \mathrm{Ca}$ and $14 \% \mathrm{P}$. This diet was fed in amounts so that energy, nitrogen and mineral requirements were met. Diet HFO was diet $C$ supplemented with $500 \mathrm{~g}$ of crystalline hydrogenated fish oil (Enerjet 98, Relasa, Sesena, Spain). Lipids of this product were $92.8 \%$ free fatty acids and $7.2 \%$ glycerides. Diet RO was diet $\mathrm{C}$ supplemented with $500 \mathrm{~g}$ rapeseed oil.

Table I. Intake and chemical composition of experimental diets.

\begin{tabular}{lccc}
\hline & & Diet & \\
\cline { 2 - 4 } & $C$ & $H F O$ & $R O$ \\
\hline & & & \\
Intake $(g$ DM/d) & & 4340 & 4340 \\
Maize silage & 4340 & 1860 & 1860 \\
Concentrates & 1860 & 60 & 60 \\
Urea & 60 & 100 & 100 \\
Mineral premix & 100 & 500 & - \\
Hydrogenated fish oil & - & - & 500 \\
Rapeseed oil & - & & \\
& & & \\
Chemical composition & & 93.5 & 93.5 \\
(g/100 g DM) & 92.9 & 36.6 & 15.6 \\
Organic matter & 39.6 & 15.6 & 13.1 \\
NDF & 16.9 & 13.1 & 10.9 \\
ADF & 14.2 & 8.6 & 8.7 \\
Crude protein & 3.7 & 0.82 & 0.82 \\
Lipids & 1.5 & & \\
Fatty acids & 0.88 & & \\
Calcium & & & \\
\hline
\end{tabular}

${ }^{1}$ Composition: $20 \%$ wheat, $20 \%$ barley, $30 \%$ beet pulp, $15 \%$ rapeseed meal, $7 \%$ soybean meal, $5 \%$ beet molasses, $1 \%$ limestone, $1 \%$ dicalcium phosphate, $0.5 \%$ magnesium oxide, $0.5 \%$ sodium chloride. 
Chemical composition of diets is given in table I. Composition of hydrogenated fish oil and rapeseed oil fatty acids is shown in table II.

Diets including lipidic supplements were fed as a total mixed ration. Cows were fed twice daily in equal portions at $09.00 \mathrm{~h}$ and $16.00 \mathrm{~h}$.

\section{Measurements}

Digestibility was measured by total collection of feces over a 5-day period. Two representative samples of feeds and feces were taken. The first was dried and used for analyses of ash, NDF and ADF; the second was frozen and then lyophilised for determination of lipids and fatty acids.

Samples of rumen liquor were taken from the ventral sac for 2 consecutive days at $09.00 \mathrm{~h}$ (before food distribution) and $11.30 \mathrm{~h}$. PH was measured immediately; a sample was taken for volatile fatty acids (VFA) determination, with orthophosphoric acid as preservative.

Nylon bags (internal size: $6 \times 11 \mathrm{~cm}$, pore size: $46 \mu \mathrm{m}$ ) were filled with $3 \mathrm{~g}$ of dry maize silage without cobs that had been ground through a $0.8-\mathrm{mm}$ screen. Triplicate bags were introduced into the ventral sac of the rumen at 09.00 $h$ and incubated for $3,6,12,24$ and $48 \mathrm{~h}$.

\section{Analyses}

Dry matter content of feeds and feces was determined by oven-drying at $80^{\circ} \mathrm{C}$ for $48 \mathrm{~h}$. Ash-

Table II. Fatty acid composition of lipidic supplements ( $g / 100 \mathrm{~g}$ methyl esters).

\begin{tabular}{lrr}
\hline & $\begin{array}{c}\text { Hydrogenated } \\
\text { fish oil }\end{array}$ & $\begin{array}{c}\text { Rapeseed } \\
\text { oil }\end{array}$ \\
\hline & & \\
C14:0 (myristic acid) & 7.3 & 0.1 \\
C16:0 (palmitic acid) & 30.4 & 5.0 \\
C18:0 (stearic acid) & 22.2 & 1.7 \\
C18:1 n-9 (oleic acid) & 0.8 & 57.6 \\
C18:2 n-6 (linolenic acid) & 0.1 & 21.1 \\
C18:3 n-3 (linolenic acid) & - & 9.4 \\
C20:0 (arachidic acid) & 20.0 & 0.6 \\
C22:0 (behenic acid) & 11.9 & 0.4 \\
\hline
\end{tabular}

ing was performed at $550^{\circ} \mathrm{C}$ for $6 \mathrm{~h}$. NDF and $A D F$ were analyzed by the method of Goering and Van Soest (1970). The difference between NDF and ADF was considered as hemicellulose. Calcium was analyzed by atomic absorption spectrophotometry. Lipid and fatty acid composition of feed and feces were determined according to the method described by Bauchart et al (1990): lipids were first extracted by the method of Folch et al (1957), then in hexane - ethanol hydrochloric acid (5:2:2, by vol), and then determined gravimetrically. Lipids were saponified and their fatty acids methylated. Methyl esters were separated by $\mathrm{GLC}$ at $195^{\circ} \mathrm{C}$ using a glass capillary column coated with FFA phase. Methyl heptadecanoate was used as the internal standard.

Concentration and composition of VFA in rumen fluid were determined by GLC (Jouany, 1982).

Nylon bags were washed in cold water before drying at $80^{\circ} \mathrm{C}$ for $48 \mathrm{~h}$ and weighing. The kinetics were adjusted to an exponential model: $D=a+b\left(1-e^{-c}\right)$ where $D$ is the percentage of DM disappearance at time $t, a$ and $b$ the rapidly and slowly degradable components, and $c$ the fractional rate of degradation of component $b$ (Ørskov and McDonald, 1979).

Statistical analyses were performed by analysis of variance with 3 factors: animal, period, treatment. When treatments differed significantly, comparisons between 2 treatments were made by a Duncan test. Results are expressed as mean and pooled standard error of the mean (SEM).

\section{RESULTS}

Organic matter digestibility was significantly lower for diets HFO and RO than for diet $C$ (table III). The cause of this drop in digestibility is not the same for diet HFO and for diet RO. Indeed, digestibility of all fibre fractions (NDF, ADF and hemicellulose) was significantly lower for diet RO than for diet $C$, but did not differ between diets HFO and C. On the contrary, apparent digestibility of all lipid fractions (total lipids, fatty acids, non-fatty acid lipids was not different between diets RO and $\mathrm{C}$, but was 
Table III. Apparent digestibility of nutrients (\%).

\begin{tabular}{lcccc}
\hline & \multicolumn{3}{c}{ Diet } & SEM \\
\cline { 2 - 4 } & $C$ & HFO & RO & \\
\hline & & & & \\
Dry matter & $77.7^{\mathrm{a}}$ & $75.0^{\mathrm{ab}}$ & $72.3^{\mathrm{b}}$ & 0.31 \\
Organic matter & $81.6^{\mathrm{a}}$ & $78.7^{\mathrm{b}}$ & $76.3^{\mathrm{b}}$ & 0.23 \\
NDF & $73.9^{\mathrm{a}}$ & $72.8^{\mathrm{a}}$ & $63.5^{\mathrm{b}}$ & 0.51 \\
ADF & $68.3^{\mathrm{a}}$ & $67.8^{\mathrm{a}}$ & $55.7^{\mathrm{b}}$ & 0.92 \\
Hemicellulose & $78.1^{\mathrm{A}}$ & $76.4^{\mathrm{A}}$ & $69.3^{\mathrm{B}}$ & 0.25 \\
Lipids & 62.5 & 45.1 & $68.3^{\mathrm{A}}$ & 1.17 \\
Fatty acids & $71.7^{\mathrm{A}}$ & $44.9^{\mathrm{B}}$ & $72.0^{\mathrm{A}}$ & 0.17 \\
16C and 18C fatty acids & $72.0^{\mathrm{A}}$ & $47.8^{\mathrm{B}}$ & $75.3^{\mathrm{A}}$ & 1.02 \\
20C fatty acid & -37.6 & 44.9 & -27.2 & 16.61 \\
22C fatty acids & 31.3 & 33.7 & -3.1 & 8.00 \\
Non-fatty acid lipids & 55.9 & 45.2 & 54.4 & 3.66 \\
& & & & \\
\hline
\end{tabular}

Values are means for 3 cows per diet. SEM: standard error of the mean. $16 \mathrm{C}, 18 \mathrm{C}, 20 \mathrm{C}$ and $22 \mathrm{C}$ represent the sum of fatty acids with $16,18,20$ and 22 carbons, respectively. Means on the same row with different superscripts differ significantly (a. b: $P<0.05 ;$ A. B: $P<0.01$ ).

lower for diet HFO. The drop in digestibility between diets $\mathrm{C}$ and HFO for lipids, fatty acids and non-fatty acid lipids was 17.4 , 26.8 and 10.7 percentage units, respectively. The trend was not significant for lipids and non-fatty acid lipids, due to a high SEM values, but was significant for fatty acids. The lower digestibility of fatty acids for diet HFO than for diets $C$ and RO was because of a low digestibility of all fatty acids, including fatty acids with 16 and 18 carbons. Although means varied, digestibility of $\mathrm{C} 20$ and $\mathrm{C} 22$ did not differ significantly among diets. Lack of significance is explained by the extremely high SEM values, caused by the very low intake for diets $\mathrm{C}$ and $\mathrm{RO}$.

The mean $\mathrm{pH}$ did not vary among diets (table IV). VFA concentration and composition show a non significant trend toward a decrease in concentration and in butyrate percentage, and a significant postprandial increase in propionate percentage for diet RO when compared to the other 2 diets.

Difference among diets was shown to be non-significant by the in sacco technique (table $\mathrm{V}$ ), either for percentages of DM disappearance at different incubation times or for parameters of the mathematical model.

\section{DISCUSSION}

The decrease in organic matter and fibre digestibilities with addition of rapeseed oil to a maize silage diet was the same as in a previous trial (Doreau et al, 1991a). In this trial as in another experiment carried out with rapeseed (Doreau et al, 1991b), the decrease in digestibility is not related to a decrease in in sacco fibre degradation. As lipid supply generally causes no variation in retention time of particles in the rumen 
Table IV. $\mathrm{pH}$, concentration and composition of volatile fatty acids in rumen liquor at two sampling times, before and $2.5 \mathrm{~h}$ after feeding.

\begin{tabular}{|c|c|c|c|c|c|}
\hline & & \multicolumn{3}{|c|}{ Diet } & \multirow[t]{2}{*}{ SEM } \\
\hline & & $C$ & HFO & RO & \\
\hline \multirow[t]{2}{*}{$\mathrm{pH}$} & $09.00 \mathrm{~h}$ & 6.91 & 6.98 & 7.13 & 0.025 \\
\hline & $11.30 \mathrm{~h}$ & 6.68 & 6.59 & 6.61 & 0.030 \\
\hline \multirow[t]{2}{*}{ Volatile fatty acids $(\mathrm{mMol} / \mathrm{l})$} & $09.00 \mathrm{~h}$ & 57.1 & 51.3 & 42.8 & 1.70 \\
\hline & $11.30 \mathrm{~h}$ & 71.7 & 76.0 & 68.6 & 5.48 \\
\hline \multirow[t]{2}{*}{ Acetate $(\mathrm{mol} / 100 \mathrm{~mol})$} & $09.00 \mathrm{~h}$ & 66.3 & 66.0 & 66.9 & 0.30 \\
\hline & $11.30 \mathrm{~h}$ & 61.7 & 61.6 & 61.4 & 0.23 \\
\hline \multirow[t]{2}{*}{ Propionate $(\mathrm{mol} / 100 \mathrm{~mol})$} & $09.00 \mathrm{~h}$ & 14.9 & 14.3 & 15.5 & 0.14 \\
\hline & $11.30 \mathrm{~h}$ & $17.5^{\mathrm{a}}$ & $17.7^{\mathrm{a}}$ & $20.7^{b}$ & 0.19 \\
\hline \multirow[t]{2}{*}{ Butyrate $(\mathrm{mol} / 100 \mathrm{~mol})$} & $09.00 \mathrm{~h}$ & 13.0 & 14.0 & 11.3 & 0.34 \\
\hline & $11.30 \mathrm{~h}$ & 13.7 & 14.2 & 11.2 & 0.30 \\
\hline
\end{tabular}

Values are means for 3 cows per diet. SEM: standard error of the mean. Means on the same row with different superscripts differ significantly $(P<0.05)$.

Table v. Degradation of dry matter in sacco: percentages of disappearance at different times of incubation and parameters of the model.

\begin{tabular}{|c|c|c|c|c|}
\hline & \multicolumn{3}{|c|}{ Diet } & \multirow[t]{2}{*}{ SEM } \\
\hline & $C$ & HFO & RO & \\
\hline \multicolumn{5}{|c|}{ Incubation time } \\
\hline $3 \mathrm{~h}$ & 39.6 & 39.1 & 39.2 & 0.24 \\
\hline $6 \mathrm{~h}$ & 43.3 & 44.4 & 42.9 & 0.31 \\
\hline $12 \mathrm{~h}$ & 51.9 & 54.6 & 50.5 & 1.37 \\
\hline $24 h$ & 64.9 & 68.1 & 62.8 & 1.50 \\
\hline $48 h$ & 74.8 & 76.5 & 71.7 & 1.40 \\
\hline \multicolumn{5}{|c|}{ Parameters of the model } \\
\hline$a(\%)$ & 33.0 & 32.9 & 30.8 & 0.87 \\
\hline$b(\%)$ & 48.7 & 45.5 & 49.7 & 2.22 \\
\hline$c(\% / h)$ & 4.33 & 4.47 & 5.61 & 0.54 \\
\hline
\end{tabular}

Values are means for 3 cows per diet. SEM: standard error of the mean.
(Ferlay et al, 1991), this lack of consistency could be explained by a negative effect of rapeseed oil on protozoal number and activity, as suggested by a decrease in butyrate proportion in rumen VFA. Protozoal action is not taken into account in in sacco measurements. Indeed, size of most protozoa species is higher than bag pore size.

The absence of changes in fibre digestion when hydrogenated fish oil was added to the diet may be because of saturated fatty acids, which are less determinant for microbial growth than unsaturated fatty acids (Maczulak et al, 1981) and to the high melting point of this fat, which may cause a by-pass of the rumen. However, when such fats are fed in large amounts, Sundstøl (1974) observed a decrease in fibre digestibility, showing that a high melting point does not prevent fat from altering ruminal fermentation. With crude fish oils, 
changes in VFA composition obtained by several authors in cows receiving 225 to $300 \mathrm{~g} / \mathrm{d}$ cod liver oil ranged from no effect (Pennington and Davis, 1975) to a large increase in propionic acid (Shaw and Ensor, 1959). The only complete digestion experiment did not show a decrease in ruminal fibre digestion (Sutton et al, 1975).

Although saturated fatty acids sometimes have a low digestibility (Jenkins and Jenny, 1989), the low digestibility of fatty acids in the HFO diet was surprising. Andrews and Lewis (1970) showed a high total digestibility of herring oil. They did not calculate digestibility of total 20- and 22carbon fatty acids, but from their results it can be estimated to be more than $80 \%$. In the same manner, Sutton et al (1975) noted a high total digestibility of fatty acids from cod liver oil. Børsting and Weisbjerg (1989) measured digestibility in the small intestine that was close to $80 \%$ for arachidic and behenic acids in cows fed protected fish oils. In contrast to an earlier idea that an increase in intake of fat caused increase in digestibility of fat, it is now thought that too much fat in the diet can depress digestibility (Tamminga and Doreau, 1991). It could be postulated that in this experiment the level of dietary arachidic and behenic acids is too high to prevent fat digestibility depression. However, Sundstøl (1974) observed high digestibility of ether extract when hydrogenated fish oil was fed to sheeps. As digestibility of all fatty acids in impaired in the present trial, the main hypothesis to explain this low digestibility is an incomplete micellar organization of fats. No evidence for this hypothesis has been shown either in ruminants or in monogastric animals. However, it should be noted that Børsting and Weisbjerg (1989) observed a lower bile acid secretion and a higher reabsorption when fish oil was fed to cows than when other fat sources were fed, although this had no consequence on digestibility of the oil.

\section{CONCLUSION}

This trial has shown the absence of negative effects of crystalline hydrogenated fish oil on rumen fibre digestion. The low intestinal digestibility of lipids has to be assessed by new experiments in which the causes of variation in intestinal absorption can be analyzed.

\section{ACKNOWLEDGMENTS}

The authors acknowledge the financial assistance of SCD Chauveau, La Brechoire, 49280 Cholet, France. Thanks are due to E Girard and $D$ Thomas for care of animals and help in sampling and to G Sauvage, J Chabrot and J Fléchet for technical assistance.

\section{REFERENCES}

Andrews RJ, Lewis D (1970) The utilization of dietary fats by ruminants. I. The digestibility of some commercially available fats. $J$ Agric Sci (Camb) 75, 47-53

Bauchart D, Legay-Carmier F, Doreau M, Gaillard B (1990) Lipid metabolism of liquidassociated and solid-adherent bacteria in rumen contents of dairy cows offered lipidsupplemented diets. Br J Nutr 63, 563-578

Børsting CF, Weisbjerg MR (1989) Fatty acid metabolism in the digestive tract of ruminants. Ph D Thesis, Inst Anim Sci Copenhagen, Denmark, 249 p

Doreau M, Ben Salem H, Krzeminski R, Legay F, Bauchart D (1991a) Ruminal nitrogen metabolism of cows fed diets supplemented or not with lipids. Proc 6th Int Symp Prot Metabol Nutr, Herning, Denmark, 64-66

Doreau $M$, Chilliard $Y$, Bauchart $D$, MichaletDoreau B (1991b) influence of different fat supplements on digestibility and ruminal digestion in cows. Ann Zootech 40, 19-30

Ferlay A, Legay F, Bauchart D, Poncet C, Doreau $M$ (1992) Effect of a supply of raw or extruded rapeseeds on digestion in dairy cows. J Anim Sci 70, 915-923 
Folch J, Lees M, Sloane Stanley GH (1957) Simple method for the isolation and purification of total lipids from animal tissues. $J$ Biol Chem 226, 497-509

Goering HK, Van Soest PJ (1970) Forage Fiber Analysis. Handbook ARS, USDA No 379 , Washington, USA

Jenkins TC, Jenny BF (1989) Effect of hydrogenated fat on feed intake, nutrient digestion, and lactation performance of dairy cows. J Dairy Sci 72, 2316-2324

Jouany JP (1982) Volatile fatty acid and alcohol determination in digestive contents, silage juices, bacterial cultures and anaerobic fermentor contents. Sci Alim 2, 131-144

Maczulak AE, Dehority BA, Palmquist DL (1981) Effects of long-chain fatty acids on growth of rumen bacteria. Appl Environ Microbiol 42, 856-862

Opstvedt $\mathrm{J}$ (1984) Fish fats. In: Fats in Animal Nutrition (Wiseman J, ed) Butterworths, London, 53-82

Orskov ER, McDonald J (1979) The estimation of protein degradability in the rumen from in- cubation measurements weighted according to rate of passage. J Agric Sci (Camb) 92, 499-503

Pennington JA, Davis CL (1975) Effects of intraruminal and intra-abomasal additions of codliver oil on milk fat production in the cow. $J$ Dairy Sci 58, 49-55

Shaw JC, Ensor WL (1959) Effect of feeding cod liver oil and unsaturated fatty acids on rumen volatile fatty acids and milk fat content. J Dairy Sci 42, 1238-1240

Sundstol F (1974) Hydrogenated marine fat as feed supplement. III. Digestibility of rations containing hydrogenated marine fat in sheep. Meld Nor Landbrukshogsk, 161, 31 pp

Sutton JD, Smith RH, McAllan AB, Storry JE, Corse DA (1975) Effect of variations in dietary protein and of supplements of cod-liver oil on energy digestion and microbial synthesis in the rumen of sheep fed hay and concentrates. J Agric Sci (Camb) 84, 317-326

Tamminga S, Doreau M (1991) Lipids and rumen digestion. In: Rumen Microbial Metabolism and Ruminant Digestion (Jouany JP, ed) INRA, Paris, 151-163 